\title{
Investigation of 10 herbicides in surface waters of a horticultural production catchment in south-eastern Australia
}

\author{
Graeme Allinson $^{\text {a,b }}$, AnhDuyen Bui ${ }^{\text {c,a }}$, Pei Zhang ${ }^{\text {c,a }}$, Gavin Rose ${ }^{\text {c,a }}$, \\ Adam M. Wightwick $^{\text {a,b,d }}$, Mayumi Allinson ${ }^{\text {a,b }}$, Vincent Pettigrove ${ }^{\text {a }}$
}

${ }^{a}$ Centre for Aquatic Pollution Identification and Management (CAPIM), University of Melbourne, Parkville Victoria 3010, Australia

${ }^{\mathrm{b}}$ Future Farming Systems Research, Department of Environment and Primary Industries, 2a Bellarine Highway, Queenscliff, Victoria 3225, Australia

${ }^{c}$ Future Farming Systems Research, Department of Environment and Primary Industries, Ernest Jones Drive, Victoria 3085, Australia

${ }^{\mathrm{d}}$ Coffey Environments, Level 1, 23 West Fyans Street, Newtown Victoria 3220, Australia

Corresponding author:

Dr Graeme Allinson

School of Chemistry, University of Melbourne, 30 Flemington Road, Parkville,

Victoria, Australia 3010

Telephone: +61-3-8344 7084

Email: gallinson@unimelb.edu.au 


\begin{abstract}
Herbicides are regularly applied in horticultural production systems and may migrate off-site, potentially posing an ecological risk to surface waterways. However, few studies have investigated the levels and potential ecotoxicological impact of herbicides in horticultural catchments in southern Australia. This study investigated the presence of 10 herbicides at 18 sites, over a five-month period in horticulturally important areas of the Yarra Valley in southeastern Australia. Seven of the 10 herbicides were detected in the streams, in $39 \%$ of spot water samples, $25 \%$ of surface sediment samples, and more than $70 \%$ of the passive sampler systems deployed. Few samples contained residues of two or more herbicides. Simazine was the herbicide most frequently detected in water, sediment and passive sampler samples, and was found at the highest concentrations in the water $(0.67 \mathrm{~g} / \mathrm{L})$, and sediment (up to $260 \mathrm{~g} / \mathrm{kg}$ dry weight). Generally the concentrations of the herbicides detected were several orders of magnitude lower than reported ecotoxicological effect values, including those for aquatic plants and algae, suggesting that concentrations of individual chemicals in the catchment were unlikely to pose an ecological risk. However, little is known about the combined effects of simultaneous, low level exposure of multiple herbicides of the same mode of action on Australian aquatic organisms, nor their contribution when found in mixtures with other pesticides. Further research is required to adequately assess the risk of pesticides in Victorian aquatic environments.
\end{abstract}

Keywords: herbicides; horticultural catchment; surface water; sediment; environmental risk 


\section{Introduction}

Herbicides are widely used in Australian agricultural productions systems for the suppression of unwanted plants (weeds) before and during crop growth. In monetary and volume terms, herbicides are the top ranked category of pesticides sold in Australia (based on 2010-11 data: 2130 products, $\mathrm{A} \$ 1,252$ million), more than twice that of insecticides (1098 products; $\mathrm{A} \$ 362$ million) and five times the sales of fungicides (619 products; A $\$ 231$ million; APVMA 2012). The herbicide use regime employed by a farmer is largely influenced by the different weed threats faced by the crops being produced. For example, there are a greater number of herbicides registered for use on wheat (40) than potatoes (22), and a relatively low number of herbicides registered for use in some horticultural systems (e.g. lettuce (6), zucchini (3)) and on nut crops (e.g. almonds (9), walnuts (7)). Consequently, there is likely to be a substantial load of herbicides being applied in many agricultural production catchments. There are over 120 herbicides (active ingredients) registered for use in Victoria, although the number and amount of herbicides used by farmers in the state is unknown because, while farmers and other users must keep written records of pesticide use, there is currently no requirement to report pesticide use to either local or centralised authority (Wightwick and Allinson, 2007).

Despite the potential environmental risks, herbicides have received little attention in Australian waterways compared to other jurisdictions (Wightwick and Allinson, 2007). The presence of herbicides in the dissolved state in the aquatic environment has been extensively studied internationally and levels in the $\mathrm{g} / \mathrm{L}$ and sub- $\mathrm{g} / \mathrm{L}$ range reported in drinking and surface water. For instance, in North America the United States Geological Survey's large, nation-wide surveys of pesticide residues in surface and ground waters produced a wealth of data for use in the environmental risk assessment of herbicides (Gillom et al., 2006). However, prior to this study, there had been no significant studies investigating herbicides in surface waters in Victoria since 
the 1990s, although in northern Australia a number of recent studies have detected residues of some herbicides, including atrazine, diuron, hexazinone, and simazine, in the water column in a relatively high percentage of samples (Shaw et al., 2010; Lewis et al., 2009; Bainbridge et al., 2009; Bengston Nash et al., 2006).

While the measurement of nutrients and salts in surface and groundwater is now routine and offered cheaply by many commercial laboratories, this is not so for other contaminants of concern, including many pesticides. Measurement of pesticides in waters and sediments can be expensive in Australia, which inhibits monitoring by water authorities (as providers of water), catchment management authorities (as custodians of the natural environment), and consumers (e.g. irrigators, industry and household and domestic water users), potentially resulting in increased risk to the natural environment. Grab (or spot) samples are commonly used to characterise pesticide residues in surface waters, although there are a number of modified or new approaches for sampling which facilitate cost-effective monitoring of pesticide concentrations in waterways, one of which is integrative sampling with passive samplers (or passive sampling). A 'passive sampler' can be defined as a device that is able to acquire a sample from discrete location without the active media transport induced by pumping or purge techniques (ITRC 2006). Hence, most passive samplers consist of a receiving phase with high affinity for organic contaminants, separated from the aquatic environment by a diffusion limiting membrane. Some of the most commonly used devices that rely on diffusion and sorption to accumulate analytes in the sampler are semi-permeable membrane devices (SPMDs) and passive in-situ samplers (such as the Chemcatcher ${ }^{\mathrm{TM}}$ system (CC)). One of the first studies in Victoria using passive samplers occurred during the 2004-05 and 2005-06 irrigation seasons, when Rose and Kibria (2007) deployed SPMDs containing trimethyl pentane at fifteen sites within six irrigation areas in northern Victoria. The monitoring found three insecticides (endosulfan, chlorpyrifos and 
parathion methyl) in the passive sampler solvents, but no herbicides. Elsewhere in Australia, a number of relatively recent studies have detected residues of some herbicides in rivers and estuaries on the eastern seaboard of Australia using CC passive sampling systems, including atrazine, diuron, hexazinone, and simazine (Escher et al., 2006; Lewis et al., 2009; Muller et al., 2008; O’Brien et al., 2011; Shaw et al., 2009, 2010; Stephens et al., 2009), but prior to this study, there had been no significant studies investigating herbicides in surface waters in Victoria using the CC system.

There has been less attention paid to levels of herbicides in sediment than in the water column, despite the potential effects they may have on benthic organisms. Noppe et al. (2007) were the first to report on the occurrence of triazines (e.g. atrazine, simazine) in suspended solids and sediment because up to that point, they contend, it had generally been assumed that these chemicals are mainly in the dissolved phase (as a group, the triazines are relatively polar (i.e. with an octanol-water partition coefficient, log Kow typically $<2.5$ ) with good water solubility (up to $30 \mathrm{mg} / \mathrm{L}$ )). Chemical sorption, however, is also influenced by the organic carbon and clay content of sediments which may combine to increase the capacity of sediments to act as reservoirs for some chemicals. This in part may explain the wide variation in concentrations observed for compounds such as atrazine in sediments, e.g. up to $9.9 \mathrm{~g} / \mathrm{kg}$ in Belgium and the Netherlands (Noppe et al. 2007), up to $170 \mathrm{~g} / \mathrm{kg}$ in Pakistan (Maqbool et al. 2008) and up to 600 $\mathrm{g} / \mathrm{kg}$ in the Fraser River valley in Canada (Wan et al. 2006). In Australia, Duke et al. (2005) reported atrazine, ametryn and diuron in mangrove sediments, with higher diuron concentrations in sediments where there were greater numbers of common mangrove (Avicennia marina) showing signs of toxicity. 
To in part address the paucity of information on herbicides in Victorian waterways, in $2008-09$ we examined the presence and concentration of 10 synthetic organic herbicide compounds plus a number of metabolites/breakdown products, in the water column and sediments at 18 surface water sites over a five month period within Victoria's Yarra River Catchment, in south-eastern Australia. The objective of this study was to generate new data on the environmental levels and possible ecological impact of herbicides used in horticultural production systems. The study included both intensive spot water and sediment sampling and time-integrated sampling via deployment of passive water samplers. To our knowledge this was the first study of its kind undertaken in horticultural catchments within Victoria. 


\section{Materials and methods}

\subsection{Study area}

Eighteen sites were monitored in Victoria's Yarra River catchment for this study, which was conducted as part of a larger, multi-disciplinary study of waterways in and around Melbourne. In that context, this manuscript is a companion piece to the paper by Wightwick et al (2012), and Wightwick et al (2013) who reported the levels of 25 fungicides and trace metals in the surface waters and sediments, respectively, at the sites in the Middle and Upper Yarra catchment area used for this study (Figure S1). For full details of the study area, readers are directed to the Supplementary Information.

\subsection{Water and sediment sampling}

Water and sediment samples were collected from each of the 18 sampling sites every four weeks from September to December 2008 and again in February and March 2009. Water temperature, $\mathrm{pH}$, and electrical conductivity (EC) were measured in-situ at the time of sampling using a field meter. The total organic carbon (TOC) content of water samples was determined according to American Public Health Association (APHA) method 5301B (APHA, 2005). Sediment samples were analysed for organic carbon (OC) using the Walkley and Black method (Rayment and Lyons, 2011, Method 6A1). The range and the mean of these water quality parameters for each of the monitoring sites was as follows: temperature $\left(15.5-18.6^{\circ} \mathrm{C}\right.$; mean $\left.16.8^{\circ} \mathrm{C}\right)$; $\mathrm{pH}(6.2-7.4$; mean 6.7); EC (81-741 S; mean $300 \mathrm{~S})$; TOC water (4.6-20 mg/L; mean $8.0 \mathrm{mg} / \mathrm{L})$; sediment OC $(2.0-7.3 \%$; mean $3.8 \%)$. For full details of spot water and sediment sampling methods, readers are directed to the Supplementary Information. 


\subsection{Passive water sampling}

Two types of passive sampler were used in this study, namely trimethyl pentane passive samplers (TRIMPs), a type of SPMD to target non-polar chemicals with $\log$ Kow $>\sim 3.5$, and the Chemcatcher $^{\mathrm{TM}}$ passive sampler system (CC) fitted with an Empore ${ }^{\mathrm{TM}}$ SDB-XC disk (3M, MN, USA) as the receiving phase and a polyethersulfone (PES) membrane as the diffusion-limiting membrane, to target polar chemicals with $\log$ Kow $<\sim 3.0$. The two types of sampler were deployed for time-integrated monitoring to allow firstly a qualitative assessment (i.e. presence/absence) and then, where possible, a semi-quantitative assessment (i.e. based on estimated time-weighted average water concentrations) of herbicides in the catchment. For full details of the passive sampling methods, readers are directed to the Supplementary Information.

\subsection{Analytical Testing Methods: Pesticides}

Analysis included 10 different herbicides and selected associated degradates registered for use in Victoria (Table 1) from the following classes: benzamide, dinitroaniline, triazine/triazinone, and urea herbicides. No one analytical method is appropriate for the measurement of all of the herbicides investigated in this study. Several different methods based on solid-phase extraction (SPE) were used to prepare the different sample matrices and chemicals (see Supplementary Information). These SPE methodologies were validated and accredited by the National Association of Testing Authorities, Australia (NATA) to ISO 17025 standard. The final extracts from the SPE clean-ups were used in several different analysis programs: volatile nitrogen containing herbicides concentrations were measured using gas chromatography-nitrogen phosphorus detector (GC-NPD), triazines with liquid chromatography-tandem mass spectrometry (LC-MS/MS), and a range of other polar herbicides using a multi-residue LC-MS/MS screen (see Supplementary Information for details of extraction methods and instrument parameters, and the 
herbicides determined with each program). The results were not corrected for recovery, which was determined by spiking randomly selected samples of each analytical batch of water and sediment samples (typically the 24 sites) with each reported herbicide. 


\section{Results and Discussion}

\subsection{Herbicides in water, passive sampler, and sediment samples}

Out of the 10 herbicides included in the analytical screens, 7 were detected in one or more water, passive sampler (TRIMPs or CC) and/or sediment samples (Table 2). Herbicides were not detected in any samples collected from the reference sites, but were detected in $39 \%$ of water samples ( 8 herbicides), $25 \%$ of the sediment samples ( 4 chemicals), $2 \%$ of the TRIMP solvents (2 chemicals), and $73 \%$ of CC disk eluates ( 3 chemicals) from the remaining sites. Simazine was the most frequently detected herbicide in water (47\% samples), sediment (18\% samples) and CC (73\% samples). All other detected herbicides were present in no more than $10 \%$ and generally less than $5 \%$ of samples. Simazine was also found to have the highest concentrations in the water samples $(0.67 \mathrm{~g} / \mathrm{L})$, with the majority of concentrations of the other herbicides detected in the water samples $<0.1 \mathrm{~g} / \mathrm{L}$. Simazine was also detected at relatively high concentrations in the sediment samples (up to $260 \mathrm{~g} / \mathrm{kg}$ ), and a high concentration of propyzamide was also observed on one occasion $(180 \mathrm{~g} / \mathrm{kg})$.

Experimentally determined sampling rates for the herbicides detected in the TRIMPs are currently not available to derive time-weighted average water concentrations (TWAWCs). However, it was possible to estimate such TWAWCs based on predicted sampling rates (i.e. based on $\log \mathrm{K}_{\mathrm{ow}}$ values). These estimates provide semi-quantitative data for which to compare to the concentrations detected in water samples. In that context, the results for the TRIMPs do not agree with those of the water samples in that the TRIMP-derived TWAWCs of terbutryn were higher than those of pendimethalin, whereas measured pendimethalin water concentrations were much higher than the single observation of terbutryn (Table 2). 
Sampling rates for the herbicides in the CCs were determined experimentally in a flow through system using a mixed dose of triazines at $1 \mathrm{~g} / \mathrm{L}$ (see Supplementary Information). The sampling rates (Rs) were: atrazine, 12.0; cyanazine 14.8; metribuzin 6.8; prometryn 10.6; simazine 8.3 and terbutryn $10.1 \mathrm{~mL} /$ day. It is natural to wonder how the sampling rates derived experimentally in this study compare with published information. There appears to be some variability (factor of 10) in reported Rs depending on calibration conditions, including whether the receiving phases, i.e. the disk, are used 'naked' or with rate limiting membranes, length of exposure and the temperature and flow of the water in the calibration system. For instance, the sampling rates reported by Shaw et al (2009) for atrazine and simazine of $140 \mathrm{ml} / \mathrm{day}$ are an order of magnitude higher than those observed in this study, perhaps due to their use of a different disk (Empore SDB-RPS with a PES membrane). Vermeirssen et al. (2009) also reported sampling rates for a range of agrochemicals that were higher than observed in this study. In that case, including atrazine (Rs, $120 \mathrm{ml} /$ day), DEA (Rs, $100 \mathrm{ml} /$ day), and terbutryn (Rs, $110 \mathrm{ml} /$ day) on Empore SDB-RPS disks plus PES membrane. As noted by Gunold et al. (2008) the SDB-RPS phase contains more sulphonic acid functional groups than the SCB-XC disk that may improve mass transfer compared to the SCB-XC disk. This in turn may explain the higher sampling rates. However, high sampling rates may result in a shorter linear uptake phase of the sampler. Thus the advantage of employing an Empore SDB-XC disk would be a longer exposure period until equilibrium is reached. Obviously, the best comparison is between sampling rates generated by groups using similar set ups. In that context, we can say that the sampling rates generated for the triazine herbicides for this study (Rs, $8-15 \mathrm{ml} /$ day) are similar to those reported by Tran et al. (2007) who suggest that the uptake of five non-ionized polar herbicides (including simazine and atrazine) onto an Empore SDB-XC disk plus PES membrane, in a laboratory continuous-flow system was linear over a 21 day period, with Rs between $21-26 \mathrm{ml} / \mathrm{day}$. Of the chemicals for 
which experimental sampling rates were generated, only atrazine and simazine were observed on the CC disks in this study. The TWAWCs generated using those experimentally determined sampling rates are about five times higher than those observed in water samples (Table 2), and, although the maximum estimated concentrations were an order of magnitude higher than observed in water samples, overall the TWAWCs broadly agree with those of the water samples in that the simazine and TWAWCs were much higher than those of atrazine (Table 2). Hexazinone was not included in the calibration experiment, so the average sampling rates for these triazine/triazone compounds was used to generate TWAWCs in agreement with those of the water samples (in that the hexazinone concentrations were lower than those of atrazine; Table 2).

The sampling rates of chemicals into passive samplers are dependent on a range of factors, both intrinsic to the passive samplers themselves, and extrinsic factors (Leonard et al 2002). Intrinsic factors that may affect uptake include the polarity of the contaminant (as measured by its $\log$ Kow), the diffusivity of the molecules that have to pass through the aqueous boundary layer, sampler design, exposure time, and concentrations of chemicals in the surrounding water. In the laboratory, a passive sampler is immersed in water spiked with the molecules of interest. The exposure media is typically controlled (temperature, agitation, contaminant concentrations, and physico-chemical parameters). All of these factors may change in the field, and one way to overcome some of the perceived issues with laboratory-derived uptake factors is to use fieldderived sampling rates. By averaging the field spot water detections of simazine at deployment and retrieval across the monthly deployments, and using the relationship between the concentration of a chemical in the receiving phase and in the related waterbody after an exposure time during this linear sampling phase (see Supplementary Information for relevant equations), a field sampling rate was determined for each month of the survey (Table 3). Only simazine was observed in water samples sufficiently often to make this process appropriate, and although the 
field Rs contains significant variation, the mean sampling rate for simazine in field samples ranged from 43 to $63 \mathrm{~mL}$ per day, or a factor of five higher than the experimentally determined CC sampling rate. This is consistent with Ibrahim et al. (2013), who observed a four-fold difference between field- and laboratory-derived sampling rates derived for atrazine and simazine for the POCIS passive sampler system. The TWAWC for simazine $(0.08 \mathrm{~g} / \mathrm{L})$ generated using the average field sampling rate $(55 \mathrm{~mL} /$ day $)$ was much closer to the actual mean simazine concentration $(0.12 \mathrm{~g} / \mathrm{L}$; Table 2). This implies that elevated transient pulses of herbicides missed by the infrequent spot water samples may have been contributing to material sorbed onto the CC disks, producing the high TWAWCs from experimentally determined sampling rates, a possibility that has been previously reported for endosulfan in irrigation water (Rose and Kibria 2007).

Fewer herbicides were expected to be detected in sediments and TRIMPs than water and CC as the sediments and TRIMPs are suited to monitoring for non-polar chemicals (i.e. $\log \mathrm{K}_{\mathrm{ow}}>3.5$ ) and most of the herbicides included in this study have $\log \mathrm{K}_{\mathrm{ow}}<3.5$. Also, the limits of reporting in sediment samples are in the order of 100 times higher in sediment compared to water for most analytes. Interestingly however, around half of the herbicides that were detected in sediments were relatively non-polar $\left(\log \mathrm{K}_{\mathrm{ow}}<3.5\right)$ (Table 2$)$ indicating that this matrix is able to capture a wide range of chemicals. That said, the more polar herbicides detected were less prevalent in sediments and TRIMPs compared with water samples and CCs (Table 2), consistent with the theory that chemical accumulation in sediments and TRIMPs is based on $\log \mathrm{K}_{\mathrm{ow}} / \log \mathrm{K}_{\mathrm{oc}}$ characteristics.

The preponderance of simazine detections across the study make it difficult to assess temporal changes in herbicide residue detections but overall the frequency at which the herbicides were 
detected in the waterways by both spot water and passive sampling was lowest in February and March 2008, and greatest in October to December 2009 (Table 4). An increase in the presence of herbicides in the Victorian Spring (October to December) was expected as this reflects the most intensive period of domestic, commercial and horticultural applications. Otherwise, there were no clear temporal trends in the concentrations of the herbicides detected in water, passive sampler or sediment samples.

This study was designed to provide an initial broad screening level investigation of herbicides in the study catchment. That simazine was detected in such a high proportion of the collected samples is a clear indication that simazine applied in the study catchment are migrating off-site. This is not to say farmers are using this chemical inappropriately, rather the results from this study suggest that the regular application of simazine can result in loading of these compounds in catchments where herbicides are a significant agricultural input. We did not target specific rain events or spray applications so it is not possible to elucidate whether or not the simazine and the other herbicides were entering the waterways diffusively or via episodic pulse events or to identify point sources of contamination. However, that the estimated TWAWCs of herbicides in CCs tended to be higher than in the spot water samples perhaps suggests that the CCs sampling may have integrated high pulse exposure concentrations of herbicides.

Our results are consistent with other Victorian data, albeit that until recently, there has again been very little monitoring of pesticides in receiving waters, e.g. rivers, streams, lakes, wetlands, in Victoria. For instance, as discussed in Radcliffe (2002), Chapman and Stranger (1993, 1994) observed atrazine, and metribuzin in surface water samples from sites within vegetable production areas of Gippsland between 1992 and 1994 but only at concentrations (3.2 and 0.28 g/L, respectively) below relevant ANZECC and ARMCANZ (2000) water quality guideline 
trigger values. The Gippsland studies did however highlight the potential for low level contamination of surface streams located in close proximity to areas of horticultural production, i.e. as in this study. Elsewhere in Australia, much of the focus of published studies of herbicide residues has been on chemicals in rivers draining the eastern seaboard of Queensland and with potential to impact on the Great Barrier Reef (Table 5). For instance, Lewis et al. (2009) found a range of triazine/triazone herbicides in the Tully-Murray, Burdekin-Townsville, and Mackay Whitsunday regions (atrazine up to $7.8 \mathrm{~g} / \mathrm{L}$; hexazinone, up to $5 \mathrm{~g} / \mathrm{L}$; and simazine, up to 0.18 $\mathrm{g} / \mathrm{L})$.

Our data is also consistent with levels reported internationally in the past 5 years. There have been a significant number of studies of herbicides in surface waters since the inception of this study, many of which have reported positive detects of one or more of the ten herbicides observed in the Yarra River and its tributaries (Table 5). While specific chemical targets reflect local land-use concerns and/or the research interests and technical capabilities of researchers, the most commonly reported herbicides are atrazine and simazine. Interestingly, in Europe, atrazine and simazine continue to be observed in water samples at concentrations similar to those observed in this study, despite the ban on their use in many countries (e.g. see Meyer et al. 2011; Silva et al. 2011; Thomatou et al. 2013; Table 5). There has been much less attention paid recently to levels of herbicides in sediment, despite the potential effects they may have on benthic primary producers. Although it is often assumed that polar chemicals such as the triazines are mainly found in the dissolved phase, chemical sorption to sediments is influenced by the type and amount of organic carbon and the clay content of sediments which may combine to increase the capacity of sediments to act as reservoirs for some chemicals. This, in part, may explain the wide variation in contaminant concentrations reported internationally in sediments for the ten herbicides screened in this study (Table 6). Sediment sampling methodology is another factor 
affecting reported concentrations, e.g. whether the whole sediment is extracted, or, as in this study, only the $64 \mathrm{~m}$ fraction, but despite this, our data is broadly consistent with the concentrations of herbicides reported internationally in sediments in the past 5 years (Table 6), where, again, the most commonly reported herbicides are atrazine and simazine.

Passive sampling has some advantages over grab water sampling in that the samplers need little attention apart from deployment and collection, and they also integrate and average exposures over time, thus enabling identification of events that may be missed by grab sampling. The major disadvantage of these methods is that the concentration data from the sampler may not be directly comparable to toxicity data based on water concentrations, and water concentrations may have to be extrapolated through the use of field or laboratory derived sampling rates, few of which are available (Gagnon et al., 2007). In addition, some chemicals may be missed, as may not readily partition into the sampler. From a practical perspective, in natural waterways samplers may be subject to periodic high-energy flows, which can wash away the samplers, and be the subject of human inquisitiveness, which may see the samplers removed from the waterway; both these externalities can reduce the integrity of a sampling program and both were experienced in this study. However, our data is also consistent with the concentrations of herbicides reported internationally using passive samplers in the past 5 years (Table 7); again the most commonly reported herbicides are atrazine and simazine.

Many studies investigating pesticides in surface waters where mixtures of chemicals are commonly detected at sampling sites (e.g. see Gillom et al. 2006; Gregoire et al. 2010), but in this study there were few instances of multiple herbicides in water samples, with three different herbicides the most detected at a single site. A similar trend was found in relation to the sediment samples, where only two samples contained residues of two different herbicides. The lack of 
multiple herbicide detections in the waterways was somewhat unexpected as different herbicidal compounds are likely to have been applied to control the different weed problems in the variety of crops present in the study catchment (Table 1). Indeed, Wightwick et al. (2012) reported that multiple fungicides were detected in Yarra Valley water sample (e.g. $31 \%$ of the water samples contained residues of two or more fungicides, and $17 \%$ containing residues of three or more fungicides). Whilst a relatively high number of common herbicides were included in this study it is recognised that there are many more herbicides registered for use in Victoria that were not included in the analytical screens, and that some of these chemicals are very commonly used in Victoria (such as glyphosate, paraquat and diquat, and some of the phenoxy acid and sulfonyl urea herbicides). Unfortunately, resource limitations prevented measurement of those chemical groups. Moreover, information on the type and quantities of herbicides being applied by the farmers was not available as it was outside the scope of this study to survey chemical use practices in this large catchment area. So it is not known how well the herbicides analysed corresponded with those being used in the catchment, and the lack of multiple residues detections may simply reflect the screening of a sub-set of the herbicides being used in the upper Yarra Valley.

\subsection{Ecotoxicological risks of herbicides detected}

Ecological risks of chemicals detected in the environment are often derived by comparisons with environmental quality values and reported ecotoxicological effects values for key sentinel aquatic species, and in Australia these are collated in the ANZECC and ARMCANZ (2000) water quality guidelines. In that context, only atrazine and simazine are in water quality guidelines, and no trigger values have been defined for any of the studied herbicides in sediments (ANZECC and ARMCANZ 2000). Because there are few formally recognised water quality guideline values available with which to compare data from this study, data on the ecotoxicological effects of 
herbicides has been taken from the IUPAC Pesticides Properties Database (University of Hertfordshire 2013; as summarised in Table 8). The ecological risk of pesticides is preferably quantified based on probabilistic methods using cumulative frequency distributions for effect and exposure concentrations. However, in the case of this study it was not necessary to go these lengths because the concentrations in water and sediment (exposure concentrations) were clearly lower than the most sensitive chronic ecotoxicological effect value for each of the herbicides (Table 8). Indeed, the concentrations detected in the waterways of this study were generally several orders of magnitude lower than ecotoxicological effect values and the few ANZECC and ARMCANZ (2000) trigger values.

Although few of the water samples in this study contained mixtures of herbicides, the presence of multiple pesticides in surface water is common in monitoring programs (Gillom et al., 2006; Gregoire et al., 2010). These mixtures of different chemicals have the potential for additive, synergistic or antagonistic effects on toxicity (ANZECC and ARMCANZ 2000). There is an increasing acknowledgement that toxic effects can occur at much lower concentrations where chemicals are present as mixtures (Baas et al., 2009). For example, a recent study has reported that the pyrethroid insecticide -cypermethrin was up to 12 times more toxic to Daphnia magna in the presence of the fungicides prochloraz, epoxiconazole and propiconazole (Nørgaard and Cedergreen, 2010). In this study most of the herbicides were photosystem II (PSII) inhibitors, and having the same mode of action, the mixtures of PSII herbicides are likely to have additive effects on algae and aquatic plants; however it is unclear what effect mixtures of herbicides with different modes of action will have on toxicity.

The study has shown the presence of residues of herbicidal compounds in the surface waters of a horticultural production catchment. Moreover, this study was conducted in a relatively dry season 
where total rainfall was approximately $40 \%$ lower than the long term mean in the catchment during the study period (BOM, 2010). Thus the risks may be greater in wetter seasons, as greater quantities of herbicides are likely to be applied and the frequency and extent of surface run-off events increased. Based on frequency of detection and concentrations, simazine is the priority herbicide of concern for the catchment studied, although we acknowledge that some commonly used herbicides (such as glyphosate, 2,4-D and MCPA) were not screened in this study. The detection of residues at so many of the surface water sites, and across sampling periods, indicates that the risks posed by this herbicide are more likely to be long-term (chronic) rather than shortterm (acute). However, the concentrations detected were relatively low and mostly several orders of magnitude below reported ecotoxicological effect and hazardous concentration values (although there are some suggestions that herbicides may cause acute risks due to high pulse exposure concentrations and this should be examined in future studies). Whilst the findings from this study indicate that individually herbicides are likely to pose a low ecological risk, the toxicity of individual herbicides and herbicidal mixtures represents a significant research gap. This study provides valuable information for policy and decision-makers, both in Australia and other regions of the world, to assess the likely risks that the use of herbicidal compounds in horticultural production systems poses to aquatic ecosystems. To progress towards a more thorough assessment of the ecological risks posed, future research should focus on gaining a better understanding of the ecotoxicological effects of priority herbicides and herbicidal mixtures, particularly to the lower trophic levels of aquatic ecosystems. 


\section{Acknowledgements}

This study was primarily supported by Melbourne Water, and the Department of Primary Industries Victoria, Australia (DPI) Future Farming Systems Research Key Project FF104 Accountable Agriculture (Project MIS \#06889, 08162), with additional support from the Centre for Aquatic Pollution Identification and Management (CAPIM). We also acknowledge Simon Phelan, David Allen, Davorka Tucman, and Debra Gill (DPI, Werribee) for assistance with sample analysis and passive sampler sampling rates experiments, as well as staff from the University of Melbourne for their help with field sampling. 


\section{References}

Anderson TA, Salice CJ, Erickson RA, McMurry ST, Cox SB, Smith LM (2013). Effects of landuse and precipitation on pesticides and water quality in playa lakes of the southern high plains. Chemosphere 92: 84-90.

ANZECC and ARMCANZ (2000). Australian and New Zealand guidelines for fresh and marine water quality. Australian and New Zealand Environment and Conservation Council/Agriculture and Resource Management Council of Australia and New Zealand, Canberra, ACT.

APHA (2005). Standard methods for the examination of water and wastewater. 21st Ed. Amercian Publich Health Association, Amercian Waterworks Association, Washington, USA.

APVMA (2012). Pesticide and veterinary medicines product sales 2010-11 Financial Year. Commonwealth of Australia Gazette No APVMA 4, Tuesday 28 February 2012.

Baas J, Jager T, Kooijman SALM (2009). A model to analyze effects of complex mixtures on survival. Ecotox Environ Safe 72: 669-676.

Bainbridge ZT, Brodie JE, Faithful JW, Sydes DA, Lewis SE (2009). Identifying the land-based sources of suspended sediments, nutrients and pesticides discharged to the Great Barrier Reef from the Tully-Murray Basin, Queensland, Australia. Mar Freshwater Res 60: 1081-1090.

Bartelt-Hunt SL, Snow DD, Damon-Powell T, Brown DL, Prasai G, Schwarz M, Kolok AS (2011). Quantitative evaluation of laboratory uptake rates for pesticides, pharmaceuticals, and steroid hormones using POCIS. Environ Toxicol Chem 30(6): 1412-1420.

Battaglin WA, Rice KC, Focazio MJ, Salmons S, Barry RX (2009). The occurrence of glyphosate, atrazine, and other pesticides in vernal pools and adjacent streams in Washington, DC, Maryland, Iowa, and Wyoming, 2005-2006. Environ Monit Assess 155: 281-307.

Belden JB, Hanson BR, McMurry ST, Smith LM, Haukos DA (2012). Assessment of the effects of farming and conservation programs on pesticide deposition in High Plains wetlands. Environ Sci Technol 46: 3424-3432.

Bengston Nash SM, Goddard J, Müller J.F. (2006). Phytotoxicity of surface waters of the Thames and Brisbane River Estuaries: A combined chemical analysis and bioassay approach for the comparison of two systems. Biosens Bioelectron 21: 2086-2093.

BOM (2010). Climate data online. Bureau of Meteorology, Commonwealth of Australia.

, Wunderlin DA (2013). Determination of priority pesticides in water samples combining SPE and SPME coupled to (Argentina). Chemosphere 90:1860-1869.

Bowmer KH, Korth W, Scott A, McCorkelle G Thomas M (1998). Pesticide monitoring in the irrigation areas of south-western NSW 1990 - 1995, Technical Report 17/98. CSIRO Land and Water, Australia. 
Byer JD, Struger J, Ed Sverko E, Klawunn P, Todd A (2011). Spatial and seasonal variations in atrazine and metolachlor surface water concentrations in Ontario (Canada) using ELISA. Chemosphere 82: 1155-1160.

Chapman RN, Stranger JW (1993). Horticultural pesticide residues in water: a survey of pesticides conducted in the Mitchell Valley, Victoria, 1992/93. Victorian Department of Agriculture, Victoria, Australia.

Chapman RN, Stranger JW (1994). Horticultural pesticide residues in water - a survey of pesticide residues conducted in Gippsland Victoria, 1994. Victorian Department of Agriculture, Victoria, Australia.

Davies PE, Cook LSJ, Barton JL (1994). Triazine herbicide contamination of Tasmanian streams: sources, concentrations and effects on biota. Aust J Mar Fresh Res 45: 209 - 226.

Devault DA, Delmotte S, Merlina G, Lim P, Gérino M, Pinelli E (2009a). Influence of in situ biological activity on the vertical profile of pre-emergence herbicides in sediment. J Environ Monit 11: 1206-1215.

Devault DA, Gérino M, Laplanche C, Julien F, Winterton P, Merlina G, Delmas F, Lim P, Sánchez-Pérez JM, Pinelli E (2009b). Herbicide accumulation and evolution in reservoir sediments. Sci Total Environ 407: 2659-2665.

Duke NC, Bell AM, Pederson DK, Roelfsema CM, Bengtson Nash S (2005). Herbicides implicated as the cause of severe mangrove dieback in the Mackay region, NE Australia: consequences for marine plant habitats of the GBR World Heritage Area. Mar Poll Bull 51: 308-324.

El-Shenawy NS, Nabil ZI, Abdel-Nabi IM, Greenwood R (2010). Comparing the passive and active sampling devices with biomonitoring of pollutants in Langstone and Portsmouth Harbour, UK. J Environ Sci Technol 3(1): 1-17.

Emelogu ES, Pollard P, Robinson CD, Webster L, McKenzie C, Napier F, Steven L, Moffat CF (2013). Identification of selected organic contaminants in streams associated with agricultural activities and comparison between autosampling and silicone rubber passive sampling. Sci Total Environ 445-446: 261-272.

Ensminger MP, Budd R, Kelley KC, Goh KS (2013). Pesticide occurrence and aquatic benchmark exceedances in urban surface waters and sediments in three urban areas of California, USA, 2008-2011. Environ Monit Assess 185(5): 3697-3710.

Escher BI, Quayle P, Muller R, Schreiber U, Mueller JF (2006). Passive sampling of herbicides combined with effect analysis in algae using a novel high-throughput phytotoxicity assay (Maxi-Imaging-PAM). J Environ Monit 8: 456-464.

-Vargas M,Moreno C (2013). Atmospheric influence on the distribution of organic pollutants in the Guadalquivir River estuary, SW Spain. Environ Monit Assess 185: 3209-3218. 
Freitas LL, Sant'Anna ES, Suchara EA, Benato VS, Carasek E (2012) Pendimethalin in surface waters of rivers in the proximity of irrigated paddy fields by solid phase microextraction and gas chromatography, Int J Environ Anal Chem 92(3): 313-323.

Gagnon B, Marcoux G, Leduc R, Pouet M-F, Thomas O (2007). Emerging tools and sustainability of water - quality monitoring. TRAC, Trends Anal Chem 26: 308-314.

Garcia-Ac A, Segura PA, Viglino L, Fürtös A, Gagnon C, Prévost M, Sauvé S (2009). On-line solid-phase extraction of large-volume injections coupled to liquid chromatography-tandem mass spectrometry for the quantitation and confirmation of 14 selected trace organic contaminants in drinking and surface water. J Chromatogr A 1216: 8518-8527

Gillom RJ, Barbash JE, Crawford CG, Hamilton PA, Martin JD, Nakagaki N, Nowell LH, Scott JC, Stackleberg PE, Thelin GP, Wolock DM, (2006). The quality of our nation's waters pesticides in the nation's streams and groundwater, 1992 - 2001. U.S Geological Survey Circular 1291. United States Geological Survey, Reston, Virginia, USA.

Gregoire C, Payraudeau S, Domange N, (2010). Use and fate of 17 pesticides applied on a vineyard catchment. Int J Environ Anal Chem 90: 406 - 420.

Gunold R, Schäfer RB, Paschke A, Schüürmann G, Liess M (2008). Calibration of the Chemcatcher ${ }^{\mathrm{TM}}$ passive sampler for monitoring selected polar and semi-polar pesticides in surface water. Environ Poll 155: 52-60

Hermosin MC, Calderon MJ, Real M, Cornejo J (2013). Impact of herbicides used in olive groves on waters of the Guadalquivir river basin (southern Spain). Agric Ecosys Environ 164: 229243.

Hladik M, Domagalski JL, Kuivila KM (2009). Concentrations and loads of suspended sedimentassociated pesticides in the San Joaquin River, California and tributaries during storm events. Sci Total Environ 408: 356-364.

Hyne RV, Aistrope M (2008). Calibration and field application of a solvent-based cellulose membrane passive sampling device for the monitoring of polar herbicides. Chemosphere 71: 611-620.

Ibrahim I, Togola A, Gonzalez C (2013). In-situ calibration of POCIS for the sampling of polar pesticides and metabolites in surface water. Talanta 116: $495-500$.

ITRC (2006). Technology overview of passive sampler technologies. DSP-4. Washington, D.C.: Interstate Technology and Regulatory Council, Authoring Team. Available on-line: www.itrcweb.org/Guidance/ListDocuments?TopicID=17\&SubTopicID=27 Last accessed 12 April 2014.

Kingston JK, Greenwood R, Mills GA, Morrison, GM, Björklund Persson L (2000). Development of a novel passive sampling system for the time averaged measurement of a range of organic pollutants in aquatic environments. J Environ Monit 2: 487-495.

Knight SS, Lizotte RE, Moore MT, Smith S, Shields FD (2009). Mississippi oxbow lake sediment quality during an artificial flood. Bull Environ Contam Toxicol 82: 496-500. 
Köck M, Farré M, Martínez E, Gajda-Schrantz K, Ginebreda A, Navarro A, López de Alda M, Barceló D (2010). Integrated ecotoxicological and chemical approach for the assessment of pesticide pollution in the Ebro River delta (Spain). J Hydrol 383: 73-82.

-Serna

(2011). Wastewater reuse in

Mediterranean semi-arid areas: The impact of discharges of tertiary treated sewage on the load of polar micro pollutants in the Llobregat river (NE Spain). Chemosphere 82: 670-678.

(2012). Analysis of the occurrence and risk assessment of polar pesticides in the Llobregat River Basin (NE Spain). Chemosphere 86: 8-16.

Kolpin DW, Blazer VS, Gray JL, Focazio MJ, Young JA, Alvarez DA, Iwanowicz LR, Foreman WT, Furlong ET, Speiran GK, Zaugg SD, Hubbard LE, Meyer MT, Sandstrom MW, Barber LB (2013). Chemical contaminants in water and sediment near fish nesting sites in the Potomac River basin: Determining potential exposures to smallmouth bass (Micropterus dolomieu). Sci Total Environ 443: 700-716.

Kouzayha A, Al Ashi A, Al Akoum R, Al Iskandarani M, Budzinski H, Jaber F (2013). Occurrence of pesticide residues in Lebanon's water resources. Bull Environ Contam Toxicol 91:503-509.

Kumar B, Gaur R, Goel G, Mishra M, Prakash D, Singh SK, Lal RB, Kumar S, Sharma CS (2011). Distribution of pesticides in sediments from municipal drains in Delhi, India. Asian J Sci Res 4(3): 271-280.

Kurt-Karakus PB, Muir DCG, Bidleman TF, Small J, Backus S, Dove A (2010). Metolachlor and atrazine in the Great Lakes. Environ Sci Technol 44: 4678-4684.

Kurt-Karakus PB, Teixeira C, Small J, Muir D, Bidleman TF (2011). Current-use pesticides in inland lake waters, precipitation, and air from Ontario, Canada. Environ Toxicol Chem 30(7): 1539-1548.

Lavado R, Loyo-Rosales JE, Floyd E, Kolodziej EP, Snyder SA, Sedlak DL, Schlenk D (2009). Site-specific profiles of estrogenic activity in agricultural areas of California's inland waters. Environ Sci Technol 43: 9110-9116.

Leonard, A.W., Hyne, R.V., Pablo, F., 2002. Trimethylpentane-containing passive samplers for predicting time-integrated concentrations of pesticides in water: Laboratory and field studies. Environ Toxicol Chem 21, 2591-2599.

Lewis SE, Brodie JE, Bainbridge ZT, Rohde KW, Davis AM, Masters BL, Maughan M, Devlin MJ, Mueller JF, Schaffelke B (2009). Herbicides: A new threat to the Great Barrier Reef. Environ Poll 157: 2470-2484.

Lissalde S, Mazzella N, Fauvelle V, Delmas F, Mazellier P, Legube B (2011). Liquid chromatography coupled with tandem mass spectrometry method for thirty-three pesticides in natural water and comparison of performance between classical solid phase extraction and passive sampling approaches. J Chromatogr A 1218: 1492-1502. 
Lizotte REJr , Knight SS, Bryant CT (2010) Sediment quality assessment of Beasley Lake: bioaccumulation and effects of pesticides in Hyalella Azteca. Chem Ecol 26(6): 411-424.

Magnusson M, Heimann K, Ridd M, Negri AP (2013). Pesticide contamination and phytotoxicity of sediment interstitial water to tropical benthic microalgae. Water Res 47: 5211-5221.

Maqbool U, Anwar-Ul-Haq, Jamil QM (2008). Comparison of in-house-developed ELISA with HPLC techniques for the analysis of atrazine residues. J Environ Sci Health B 43(3): $224-$ 230.

Martínez Bueno MJ, Hernando MD, Agüera A, Fernández-Alba AR (2009). Application of passive sampling devices for screening of micro-pollutants in marine aquaculture using $\mathrm{LC}-$ MS/MS. Talanta 77: 1518-1527.

Matamoros V, Jover E, Bayona JM (2010). Part-per-trillion determination of pharmaceuticals, pesticides, and related organic contaminants in river water by solid-phase extraction followed by comprehensive two-dimensional gas chromatography time-of-flight mass spectrometry. Anal Chem 82: 699-706.

Mazzella N, Lissalde S, Moreira S, Delmas F, Mazellier P, Huckins JN (2010). Evaluation of the use of performance reference compounds in an Oasis-HLB adsorbent based passive sampler for improving water concentration estimates of polar herbicides in freshwater. Environ Sci Technol 44: 1713-1719.

McMahon K, Bengston Nash S, Eaglesham G, Müller JF, Duke NC, Winderlich S (2005). Herbicide contamination and the potential impact to seagrass meadows in Hervey Bay, Queensland, Australia. Mar Poll Bull 51: 325-334.

Meyer B, Pailler J-Y, Guignard C, Hoffmann L, Krein A (2011). Concentrations of dissolved herbicides and pharmaceuticals in a small river in Luxembourg. Environ Monit Assess 180: $127-146$.

Mitchell C, Brodie J, White I (2005). Sediments, nutrients and pesticide residues in event flow conditions in streams of the Mackay Whitsunday Region, Australia. Mar Poll Bull 51: 23-36.

Muendo BM,Lalah JO, Getenga ZM (2011). Behavior of pesticide residues in agricultural soil and adjacent River Kuywa sediment and water samples from Nzoia sugarcane belt in Kenya. Environmentalist 32: 433-444.

Muller R, Schreiber U, Escher BI, Quayle P, Bengston Nash SM, Mueller JF (2008). Rapid exposure assessment of PSII herbicides in surface water using a novel chlorophyll a fluorescence imaging assay. Sci Total Environ 401: 51-59.

Muschal M, Warne MStJ. (2003). Risk posed by pesticides to aquatic organisms in rivers of northern inland New South Wales, Australia. Human Ecol Risk Assess 9: 1765-1787.

MWH (2007) Drinking water quality risks in Melbourne's open water supply catchments: development of a risk quantifcation. Final report. Melbourne Water, Melbourne Australia.

Nödler K, Licha T, Bester K, Sauter M (2010). Development of a multi-residue analytical method, based on liquid chromatography-tandem mass spectrometry, for the simultaneous 
determination of 46 micro-contaminants in aqueous samples. J Chromatog A 1217: 65116521 .

Noppe H, Ghekiere A, Verslycke T, De Wulf E, Verheyden K, Monteyne E, Polfliet K, van Caeter P, Janssen CR, De Brabander HF (2007). Distribution and ecotoxicity of chlorotriazines in the Scheldt Estuary (B-Nl). Environ Poll 147: 668-676.

Nørgaard, K., Cedergreen, N., 2010. Pesticide cocktails can interact synergistically on aquatic crustaceans. Environ Sci Poll Res 17, 957-967.

O'Brien D, Bartkow M, Mueller JF (2011). Determination of deployment specific chemical uptake rates for SDB-RPD Empore disk using a passive flow monitor (PFM). Chemosphere 83: $1290-1295$.

Pesce S, Morin S, Lissalde S, Montuelle B, Mazzella N (2011). Combining polar organic chemical integrative samplers (POCIS) with toxicity testing to evaluate pesticide mixture effects on natural phototrophic biofilms. Environ Pollut 159: 735-741.

Pfeuffer RJ (2011). South Florida Water Management District ambient pesticide monitoring network: 1992 to 2007. Environ Monit Assess 182:485-508.

Phong TK, Yoshino K, Hiramatsu K, Harada M, Inoue T (2010). Pesticide discharge and water management in a paddy catchment in Japan. Paddy Water Environ 8: 361-369.

Polard T, Jean S, Gauthier L, Laplanche C, Merlina G, Sánchez-Pérez J, Pinelli E (2011). Mutagenic impact on fish of run off events in agricultural areas in south-west France. Aquatic Toxicol 101(1): 126-134.

Radcliffe JC (2002). Pesticide use in Australia: a review undertaken by the Australian Academy of Technological Sciences and Engineering. Australian Academy of Technological Sciences and Engineering, Victoria, Australia.

Rayment GE, Lyons DJ (2011). Soil Chemical Methods - Australasia. CSIRO Publishing, Collingwood Australia.

Ricart M, Guasch H, Barceló D, Brix R, Conceição MH, Geiszinger A, López de Alda MJ, López-Doval JC, Muñoz I, Postigo C, Romaní M, Villagrasa M, Sabater S (2010). Primary and complex stressors in polluted Mediterranean rivers: Pesticide effects on biological communities. J Hydrol 383: 52-61.

Rose G, Kibria G (2007). Pesticide and Heavy and Metal residues in Goulburn-Murray Irrigation water 2004-06 Aust J Ecotoxicol 13: 65-79.

Sangchan W, Hugenschmidt C, Ingrwersen J, Schwadorf K, Thavornyutikarn P, Pansombat K, Streck T (2012). Short-term dynamics of pesticide concentrations and loads in a river of an agricultural watershed in the outer tropics. Agric Ecosys Environ 158: 1-14.

Schäfer, R.B., Pettigrove, V., Rose, G., Allinson, G., Wightwick, A., von der Ohe, P.C., Shimeta, J., Kuhne, R., Kefford, B.J. (2011). Effects of pesticides monitored with three sampling methods in 24 Sites on macroinvertebrates and microorganisms. Environ Sci Technol 45: $1665-1672$. 
Shaw M, Eaglesham G, Mueller JF (2009). Uptake and release of polar compounds in SDB-RPS Empore $^{\mathrm{TM}}$ disks; implications for their use as passive samplers. Chemosphere 75: 1-7.

Shaw M, Furnas MJ, Fabricius K, Haynes D, Carter S, Eaglesham G, Mueller JF (2010). Monitoring pesticides in the Great Barrier Reef. Mar Poll Bull 60: 113-122.

Silva E, Batista S, Caetano L, Cerejeira MJ, Chaves M, Jacobsen S-E (2011). Integrated approach for the quality assessment of freshwater resources in a vineyard area (South Portugal). Environ Monit Assess 176(1-4): 331-341.

Smiley PC Jr, Gillespie RB, King KW, Huang C (2009). Management implications of the relationships between water chemistry and fishes within channelized headwater streams in the midwestern United States. Ecohydrol 2: 294-302.

St. George T, Vlahos P, Harner T, Helm P, Wilford B (2011). A rapidly equilibrating, thin film, passive water sampler for organic contaminants; characterization and field testing. Environ Pollut 159: 481-486.

Stephens BS, Kapernick AP, Eaglesham G, Mueller JF (2009). Event monitoring of herbicides with naked and membrane-covered Empore disk integrative passive sampling devices. Mar Pollut Bull 58: 1116-1122.

Sun X, Zhou Q, Wang Y, Ren W (2013). Influence of hydro-geomorphology, land-use and riparian zone characteristics on herbicide occurrence and distribution in sediments in Songhua River Basin, northeastern China. Geoderma 193-194: 156-164.

Taghavi L; Probst J-L; Merlina G; Marchand A-L; Durbe G; Probst A (2010). Flood event impact on pesticide transfer in a small agricultural catchment (Montoussé at Auradé, south west France). Int J Environ Anal Chem 90(3) 390 - 405.

Taghavi L, Merlina G, Probst J-L (2011). The role of storm flows in concentration of pesticides associated with particulate and dissolved fractions as a threat to aquatic ecosystems. Case study: the agricultural watershed of Save river (Southwest of France). Knowledge Manag Aquatic Ecosys 400, 06. DOI: 10.1051/kmae/2011002.

Thitiphuree T, Kitana J, Varanusupakul P, Kitana N (2013). Atrazine contamination and potential health effects on freshwater mussel Uniandra contradens living in agricultural catchment in Nan Province, Thailand. EnvironmentAsia 6(1): 13-18.

Thomatou A-A, Zacharias I, Hela D, Konstantinou I (2013). Determination and risk assessment of pesticide residues in lake Amvrakia (W. Greece) after agricultural land use changes in the lake's drainage basin. Int J Environ Anal Chem 93(7): 780-799.

Tran ATK, Hyne RV, Doble P (2007). Calibration of a passive sampling device for timeintegrated sampling of hydrophilic herbicides in aquatic environments. Environ Toxicol Tsuda T, Nakamura T, Inoue A, Tanaka K (2009a). Pesticides in water and sediment from littoral area of Lake Biwa. Bull Environ Contam Toxicol 82: 683-689.

University of Hertfordshire (2013). The Pesticide Properties DataBase (PPDB) developed by the Agriculture \& Environment Research Unit (AERU), University of Hertfordshire, 2006-2013. 
Available online at: http://sitem.herts.ac.uk/aeru/iupac/index.htm Last accessed 18 March 2014.

Vermeirssen ELM, Bramaz N, Hollender J, Singer H, BI Escher (2009). Passive sampling combined with ecotoxicological and chemical analysis of pharmaceuticals and biocides evaluation of three Chemcatcher ${ }^{\mathrm{TM}}$ configurations. Water Res 43: 903-914.

Villaverde J, Hildebrandt A, (2008). Priority pesticides and their degradation products in river sediments from Portugal. Sci Total Environ 390: 507-513.

Vogel JR, Linard JI (2011). Agricultural herbicide transport in a first- order intermittent stream, Nebraska, USA. Appl Eng Agric 27(1): 63- 74.

Vryzas Z, Vassiliou G, Alexoudis C, Papadopoulou-Mourkidou E (2009). Spatial and temporal distribution of pesticide residues in surface waters in northeastern Greece. Water Res 43: 110.

Wan MT, Kuo J, McPherson B, Pasternak J (2006). Triazine and metolachlor herbicide residues in farm areas of the Lower Fraser Valley, British Columbia, Canada. J Environ Sci Health Part B 41: 855-867.

Whitall D, Hively WD, Leight AK, Hapeman CJ, McConnell LL, Fisher T, Rice CP, Codling E, McCarty GW, Sadeghi AM, Gustafson A, Bialek K (2010). Pollutant fate and spatio-temporal variability in the Choptank River estuary: Factors influencing water quality. Sci Total Environ 408: 2096-2108.

Wightwick A, Allinson G (2007). Pesticide residues in Victorian waterways: a review. Aus J Ecotoxicol 13: 91-112.

Wightwick A, Bui A, Zhang P, Rose G, Allinson M, Myers J, Reichman SM, Menzies NW, Pettigrove V, Allinson G (2012). Investigation of 25 fungicides in surface waters of a horticultural production catchment in south-eastern Australia. Arch Environ Contam Toxicol 62: $380-390$.

Wightwick A, Croatto G, Reichman SM, Menzies NW, Pettigrove V, Allinson G (2013). Horticultural use of copper-based fungicides has not increased copper concentrations in sediments in the mid- and upper Yarra Valley. Water Air Soil Poll 224(12): 1701. DOI $10.1007 / \mathrm{s} 11270-013-1701-3$

Woudneh MB, Ou Z, Sekela M, Tuominen T, Gledhill M (2009). Pesticide multiresidues in waters of the Lower Fraser Valley, British Columbia, Canada. Part II. Surface water. J Environ Qual 38: 940-947.

Xing Z, Chow L, Rees H, Meng F, Li S, Ernst B, Benoy G, Zha T, Hewitt LM (2013). Influences of sampling methodologies on pesticide-residue detection in stream water. Arch Environ Contam Toxicol 64: 208-218.

Yu Z, Qin Z, Ji H, Du X, Chen Y, Pan P, Wang H, Liu Y (2010). Application of SPE using multiwalled carbon nanotubes as adsorbent and rapid resolution LC-MS-MS for the simultaneous 
determination of 11 triazine herbicides residues in river water. Chromatographia 72(11-12): 1073-1081. 
Tables 
Table 1 Summary of partitioning properties of the herbicides investigated and their registered use in Victoria

\begin{tabular}{|c|c|c|c|c|c|c|}
\hline Active & $\begin{array}{l}\text { Chemical } \\
\text { Group }\end{array}$ & $\underset{\mathbf{K}_{\mathbf{o w}}}{\mathbf{L o g}}$ & $\begin{array}{l}\mathbf{L o g} \\
\mathbf{K}_{\mathbf{o c}}\end{array}$ & $\begin{array}{l}\text { Half-life } \\
\text { water } \\
\text { (days) }^{c}\end{array}$ & $\begin{array}{l}\text { Number } \\
\text { registered } \\
\text { products }\end{array}$ & Registered use $^{d}$ \\
\hline atrazine & triazine & 2.7 & 2.0 & 86 & 73 & $\begin{array}{l}\text { Legumes (lupins), roots and tubers (potatoes), cereal grains (maize, sorghum, wheat), } \\
\text { oilseeds (canola), pasture (grass pasture, lucerne), control of sedges and woody weeds } \\
\text { in forestry }\end{array}$ \\
\hline cyanazine & triazine & 2.1 & 2.3 & $\mathrm{~s}$ & 7 & $\begin{array}{l}\text { Bulb vegetables (onion), legumes (bean, chickpeas, field pea), roots and tubers } \\
\text { (potatoes) }\end{array}$ \\
\hline hexazinone & triazinone & 1.2 & 1.7 & 56 & 27 & $\begin{array}{l}\text { Control of sedges and woody weeds in forestry, spot killing of weeds in pasture, } \\
\text { commercial and industrial }\end{array}$ \\
\hline linuron & urea & 3.0 & 2.9 & 1460 & 5 & $\begin{array}{l}\text { Bulb vegetables (onion), cereal grains (barley, maize, oats, soybean, wheat), roots and } \\
\text { tubers (potatoes, carrots, parsnips), coriander }\end{array}$ \\
\hline metribuzin & triazinone & 1.7 & 1.8 & $\mathrm{~s}$ & 40 & $\begin{array}{l}\text { Asparagus, barley, chickpeas, faba beans, lentils, lupins, oats, pea, potatoes, soybeans, } \\
\text { tomatoes, vetch, wheat }\end{array}$ \\
\hline pendimethalin & dinitroaniline & 5.2 & 4.2 & $\mathrm{~s}$ & 32 & $\begin{array}{l}\text { Sunflowers, barley wheat, peas, chickpeas, faba beans, lupins and safflower, canola, } \\
\text { carrots, avocadoes, bananas, citrus, deciduous fruits, grapevines, lychees, macadamia } \\
\text { nut, mangoes, nuts, Eucalypt forestry plantation, turf }\end{array}$ \\
\hline prometryn & triazine & 3.3 & 2.6 & $\mathrm{~s}$ & 14 & Carrots, celery, pastures, perennial grass seed crops, potatoes \\
\hline propyzamide & benzamide & 3.3 & 2.9 & $\mathrm{~s}$ & 46 & Turf, lettuce, pasture (lucerne, clover), legume seed crops, \\
\hline simazine & triazine & 2.3 & 2.1 & 96 & 93 & $\begin{array}{l}\text { Algae (in swimming pools, ponds and aquaria), canola, fab beans, commercial and } \\
\text { industrial, asparagus, berry fruits, citrus, gladioli, hops, roses, chickpeas, strawberry, } \\
\text { lucerne pastures, lupins, apples and pears, vines, forestry }\end{array}$ \\
\hline terbutryn & triazine & 3.7 & 3.4 & $\mathrm{~s}$ & 17 & Barley, pastures, some varieties of oats and field peas, triticale, wheat \\
\hline
\end{tabular}

${ }^{\mathrm{a}}$, $\log \mathrm{K}_{\mathrm{ow}}$, logarithm of octanol-water partitioning co-efficient; ${ }^{\mathrm{b}}, \log \mathrm{K}_{\mathrm{oc}}$, logarithm of organic carbon adsorption coefficient ${ }^{\mathrm{c}}$, data from Wightwick and Allinson (2008b), updated using University of Hertfordshire (2010); ${ }^{\mathrm{d}}$, products registered for use in Victoria, Australia, data from APVMA website; ${ }^{\mathrm{e}}$, includes cantaloupe, cucumber, honeydew and muskmelon, pumpkin, squash, rockmelon, watermelon; ${ }^{\mathrm{f}}$, includes chrysanthemums, geraniums, iris and other ornamental flowers; ${ }^{\mathrm{g}}$, brassica vegetables, includes broccoli, Brussels sprouts, cabbages, cauliflowers; , s, stable to hydrolytic degradation in water (University of Hertfordshire 2013); DEA, desethyl atrazine; DIA, desisopropyl atrazine 
Table 2 The frequency of detection and concentrations of herbicides detected in water, sediment samples and passive sampler extracts

\begin{tabular}{|c|c|c|c|c|c|c|c|c|c|c|c|c|c|c|c|c|c|c|c|c|}
\hline \multirow[t]{2}{*}{ Active } & \multicolumn{5}{|c|}{$\begin{array}{c}\text { Water } \\
(n=106)\end{array}$} & \multicolumn{5}{|c|}{$\begin{array}{r}\text { Sediment } \\
(\mathrm{n}=106)\end{array}$} & \multicolumn{5}{|c|}{$\begin{array}{l}\text { TRIMPs } \\
(\mathrm{n}=127)^{\mathrm{c}}\end{array}$} & \multicolumn{5}{|c|}{$\begin{array}{c}C C \\
(n=89)^{d}\end{array}$} \\
\hline & FOD $^{\mathbf{a}}$ & Mean $^{b}$ & Med & Min & Max & FOD $^{\mathrm{a}}$ & Mean & Med & Min & Max & FOD $^{a}$ & Mean & Med & Min & $\operatorname{Max}$ & FOD $^{a}$ & Mean & Med & Min & $\operatorname{Max}$ \\
\hline & \multicolumn{5}{|c|}{$(g / L)$} & \multicolumn{5}{|c|}{ ( g/kg dry weight) } & \multicolumn{5}{|c|}{$(\mathrm{g} / \mathrm{L})$} & \multicolumn{5}{|c|}{$(\mathbf{L})$} \\
\hline atrazine & 6 & 0.01 & 0.01 & 0.01 & 0.02 & 1 & 2 & & & & 0 & & & & & 4 & 0.07 & 0.05 & 0.04 & 0.13 \\
\hline cyanazine & 0 & & & & & 0 & & & & & 0 & & & & & 0 & & & & \\
\hline hexazinone & 1 & 0.01 & & & & 0 & & & & & 0 & & & & & 10 & 0.03 & 0.03 & 0.02 & 0.05 \\
\hline linuron & 1 & 0.003 & & & & 1 & 3.5 & 3.5 & 2 & 5 & 0 & & & & & $\mathrm{~nm}$ & & & & \\
\hline metribuzin & 0 & & & & & 0 & & & & & 0 & & & & & 0 & & & & \\
\hline pendimethalin & 5 & 0.03 & 0.02 & 0.01 & 0.04 & 0 & & & & & 1 & 0.002 & & & & $\mathrm{~nm}$ & & & & \\
\hline prometryn & 0 & & & & & 0 & & & & & 0 & & & & & 0 & & & & \\
\hline propyzamide & 0 & & & & & 1 & 180 & & & & 0 & & & & & $\mathrm{~nm}$ & & & & \\
\hline simazine & 47 & 0.12 & 0.05 & 0.01 & 0.67 & 18 & 19 & 4 & 2 & 260 & 0 & & & & & 73 & 0.52 & 0.20 & 0.03 & 3.20 \\
\hline terbutryn & 1 & 0.001 & & & & 0 & & & & & 2 & 0.005 & 0.005 & 0.005 & 0.005 & 0 & & & & \\
\hline DEA & 1 & 0.001 & & & & 0 & & & & & 0 & & & & & 0 & & & & \\
\hline DIA & 1 & 1.3 & & & & 0 & & & & & 0 & & & & & 0 & & & & \\
\hline HA & 0 & & & & & 0 & & & & & 0 & & & & & 0 & & & & \\
\hline
\end{tabular}


Table 3 Field determined sampling rates for simazine

\begin{tabular}{|c|c|c|c|c|}
\hline \multicolumn{5}{|c|}{ Field sampling rate } \\
\hline & Oct-08 & Nov-08 & Dec-08 & Mar-09 \\
\hline \multicolumn{5}{|c|}{ (mL/day) } \\
\hline mean & 63 & 70 & 45 & 43 \\
\hline $\mathrm{CV} \%$ & 88 & 123 & 65 & 76 \\
\hline count $^{a}$ & 10 & 8 & 9 & 4 \\
\hline
\end{tabular}

Table 4 Temporal trends in the frequency in which three most commonly observed herbicides were detected in water samples

\begin{tabular}{lcccccc}
\hline Active & \multicolumn{5}{c}{ Frequency of Detection (\%) } \\
\hline & September & October & November & December & February & March \\
\hline atrazine & 0 & 0 & 0 & 6 & 17 & 0 \\
pendimethalin & 0 & 17 & 6 & 4 & 0 & 31 \\
simazine & 56 & 33 & 50 & 50 & 17 & 13 \\
\hline${ }^{a}$ FOD (\%): (number of samples chemical detected / total number of samples collected) x 100
\end{tabular}


Table 5 Selected recent studies in Australia (post-1990) and overseas (post-2009) in which residues of one or more of the herbicides examined in this study have been reported in surface waters (freshwater wetlands, creeks, rivers and lakes).

\begin{tabular}{|c|c|c|c|c|c|c|c|c|c|c|c|c|}
\hline \multirow[t]{2}{*}{ Country } & \multirow[t]{2}{*}{ Region } & \multicolumn{10}{|c|}{$\begin{array}{l}\text { Herbicides concentration } \\
(\max ; \mathrm{g} / \mathrm{L})\end{array}$} & \multirow[t]{2}{*}{ Reference } \\
\hline & & ATR & CYN & HEX & LIN & MZN & PEN & PRM & PRO & SIM & TER & \\
\hline & Australia & & & & & & & & & & & \\
\hline \multirow[t]{3}{*}{ Victoria } & Yarra valley & 0.02 & & 0.01 & 0.003 & & 0.04 & & & 0.67 & 0.001 & This study \\
\hline & Gippsland & 0.92 & & & & & & & & & & Chapman and Stranger (1993) \\
\hline & & 3.2 & & & & 0.28 & & & & 0.61 & & Chapman and Stranger (1994) \\
\hline \multirow{2}{*}{$\begin{array}{l}\text { New South } \\
\text { Wales }\end{array}$} & South-west & 4.4 & & & & & & & & & & Bowmer et al. (1998) \\
\hline & Mcintyre, Namoi, Gwydir R & 4.0 & & & & & 0.2 & 4.0 & & 0.3 & & Muschal and Warne (2003) \\
\hline \multirow[t]{6}{*}{ Queensland } & Mackay region & 0.047 & & 0.261 & & & & & & 0.016 & & Duke et al. (2005) \\
\hline & Hervey Bay basin & 0.110 & & & & & & & & 0.050 & & McMahon et al. (2005) \\
\hline & Mackay Whitsunday & 4.1 & & 1.0 & & & & & & & & Mitchell et al. (2005) \\
\hline & Brisbane $\mathrm{R}$ & 0.009 & & 0.002 & & & & & & 0.043 & & Bengston Nash et al. (2006) \\
\hline & & 1.0 & & 3.6 & & & & & & & & Bainbridge et al. (2009) \\
\hline & eastern & 7.8 & & 5.0 & & & & & & 0.18 & & Lewis et al. (2009)* \\
\hline \multirow[t]{2}{*}{ Tasmania } & & 53000 & 5.2 & 478 & & 1.3 & & & 3.3 & & & Davies et al. (1994) \\
\hline & International & & & & & & & & & & & \\
\hline Argentina & & 0.434 & & & & & & & & & & Bonansea et al. (2013) \\
\hline Brazil & Santa Catarina & & & & & & 0.38 & & & & & Freitas et al. (2012) \\
\hline \multirow[t]{6}{*}{ Canada } & Québec & 0.053 & 0.004 & & & & & & & 0.022 & & Garcia-Ac et al. (2009) \\
\hline & British Columbia & 0.053 & & 0.017 & 1.050 & 0.002 & & & & 0.896 & & Woudneh et al. (2009) \\
\hline & Great Lakes & 0.061 & & & & & & & & & & Kurt-Karakus et al. (2010) \\
\hline & Ontario & 3.91 & & & & & & & & & & Byer et al. (2011) \\
\hline & Ontario & 0.037 & & & 0.004 & 0.023 & 0.008 & & & & & Kurt-Karakus et al. (2011) \\
\hline & Maritime region & & & & 0.028 & 0.11 & & & & & & Xing et al. (2013) \\
\hline China & Heilongjiang & 0.4 & & & & & & & & 0.1 & & Yu et al. (2010) \\
\hline
\end{tabular}


Table $5\left(\right.$ cont $\left.^{\mathrm{d}}\right)$

\begin{tabular}{|c|c|c|c|c|c|c|c|c|c|c|c|c|}
\hline \multirow[t]{2}{*}{ Country } & \multirow[t]{2}{*}{ Region } & \multicolumn{10}{|c|}{$\begin{array}{l}\text { Herbicides concentration } \\
\text { (max; g/L) }\end{array}$} & \multirow[t]{2}{*}{ Reference } \\
\hline & & ATR & CYN & HEX & LIN & MZN & PEN & PRM & PRO & SIM & TER & \\
\hline \multirow[t]{4}{*}{ France } & Midi-Pyrénées & & & & 0.9 & & 0.2 & & & & & Taghavi et al. (2010)* \\
\hline & Save R, Gascogne & 0.08 & 0.02 & 0.03 & 0.04 & & 0.01 & & & 0.02 & & Polard et al. (2011) \\
\hline & Gascogne & & & & 1.65 & & & & & & & Taghavi et al. (2011) \\
\hline & Rhone R, Gard & 0.014 & & & & & & & & 0.004 & & Ibrahim et al. $(2013 *$ \\
\hline \multirow[t]{2}{*}{ Greece } & Evros R basin & 0.6 & & & & & & 0.05 & & 0.6 & & Vryzas et al. (2009)* \\
\hline & Lake Amvrakia & 0.328 & & & & & 0.020 & 0.094 & & 0.056 & & Thomatou et al. (2013) \\
\hline Luxembourg & & 0.118 & & & 0.020 & & & & & 0.038 & & Meyer et al. (2011) \\
\hline Kenya & River Kuywa & 0.15 & & 0.65 & & & & & & & & Muendo et al. (2011) \\
\hline Japan & Kose R, Fukuoka & & & & & & & & & 0.03 & & Phong et al. (2010) \\
\hline Lebanon & & & & & & & 0.010 & & & & & Kouzayha et al. (2013) \\
\hline \multirow[t]{7}{*}{ Spain } & Ebro R & 0.039 & & & 0.015 & & & & & 0.667 & & Köck et al. (2010) \\
\hline & Catalonia & 0.017 & & & & & & & & 0.013 & 0.054 & Matamoros et al. (2010) \\
\hline & Llobregat R, Barcelona & 0.0001 & & & 0.327 & & & & & 0.0054 & & Ricart et al. (2010) \\
\hline & Llobregat R, Catalonia & 0.002 & & & & & & & & 0.005 & & ck-Schulmeyer et al. (2011) \\
\hline & Llobregat R, Catalonia & 0.010 & 0.009 & & & & & & & 0.038 & & ck-Schulmeyer et al. (2012) \\
\hline & Guadalquivir R basin & 0.022 & & & & & & & & 0.405 & 0.049 & . (2013) \\
\hline & Guadalquivir R basin & 2.1 & & & & & & & & 6.7 & & Hermosin et al. (2013) \\
\hline Thailand & Mae Sa R basin & 0.4 & & & & & & & & & & Sangchan et al. (2012) \\
\hline
\end{tabular}


Table $5\left(\right.$ cont $\left.^{\mathrm{d}}\right)$

\begin{tabular}{|c|c|c|c|c|c|c|c|c|c|c|c|c|}
\hline \multirow[t]{2}{*}{ Country } & \multirow[t]{2}{*}{ Region } & \multicolumn{10}{|c|}{$\begin{array}{l}\text { Herbicides concentration } \\
\text { (max; g/L) }\end{array}$} & \multirow[t]{2}{*}{ Reference } \\
\hline & & ATR & CYN & HEX & LIN & MZN & PEN & PRM & PRO & SIM & TER & \\
\hline \multirow[t]{9}{*}{ USA } & IA, DC, MD, WY & 26.2 & & & & & & & & & & Battaglin et al. (2009) \\
\hline & California & & & & & & & & & 0.004 & & Lavado et al. (2009) \\
\hline & Cedar Ck, Indiana & 90 & & & & & & & & 30 & & Smiley et al. (2009) \\
\hline & Choptank R & 1.8 & & & & & & & & 1.9 & & Whitall et al. (2010) * \\
\hline & South Florida & 12 & & 1.3 & & 0.071 & & & & 7.3 & & Pfeuffer (2011) \\
\hline & Nebraska & 191 & & & & & & & & & & Vogel and Linard (2011) \\
\hline & Texas & & & & & & 11.3 & & & & & Anderson et al. (2013) \\
\hline & California & & & & & & 1.02 & & & 0.10 & & Ensminger et al. (2013) \\
\hline & upper Potomac R basin & 0.071 & & & & & & & & 0.053 & & Kolpin et al. (2013) \\
\hline
\end{tabular}

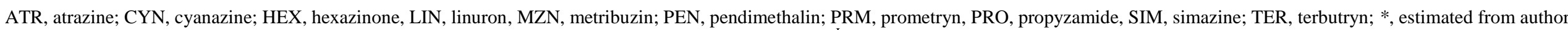

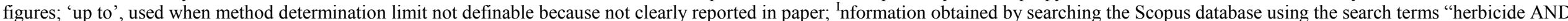

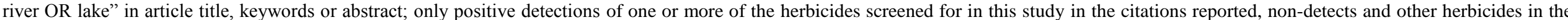
listed citations, and studies where no herbicides were examined/detected are not reported. 
Table 6 Selected recent studies in Australia (post-1990) and overseas (post-2009) in which residues of one or more of the herbicides examined in this study have been reported in sediment (freshwater wetlands, creeks, lakes, rivers and estuaries).

\begin{tabular}{|c|c|c|c|c|c|c|c|c|c|c|c|c|}
\hline \multirow[t]{2}{*}{ Country } & \multirow[t]{2}{*}{ Region } & \multicolumn{10}{|c|}{$\begin{array}{l}\text { Herbicides concentration } \\
(\mathrm{max} ; \mathrm{g} / \mathrm{kg})\end{array}$} & \multirow[t]{2}{*}{ Reference } \\
\hline & & ATR & CYN & HEX & LIN & MZN & PEN & PRM & PRO & SIM & TER & \\
\hline & Australia & & & & & & & & & & & \\
\hline Victoria & Yarra valley & 2 & & & 5 & & & & 180 & 260 & & This study \\
\hline \multirow{3}{*}{ Queensland } & Mackay region & 0.2 & & & & & & & & & & Duke et al. (2005) \\
\hline & Mackay region & 1.3 & & 1.5 & & & 4.5 & & & 0.6 & & Magnussen et al. (2013) * \\
\hline & nternational & & & & & & & & & & & \\
\hline China & Songhua River basin & 42 & & & & & & & & & & Sun et al. (2013)* \\
\hline \multirow[t]{2}{*}{ France } & s.w France & & 2651 & & 73 & & & & & 201 & & Devault et al. (2009a) \\
\hline & s.w. France & 850 & 3620 & & 3630 & & & & & 640 & & Devault et al. (2009b) \\
\hline India & Delhi & & & & & & 53 & & & & & Kumar et al. (2011) \\
\hline Kenya & & 740 & & 390 & & & & & & & & Muendo et al. (2011) \\
\hline Spain & Llobregat R, Barcelona & 0.86 & & & & & & & & 0.81 & & Ricart et al. (2010) \\
\hline Thailand & Nan Province & 230 & & & & & & & & & & Thitiphuree et al. (2013) \\
\hline \multirow[t]{5}{*}{ USA } & San Joaquin R, CA & & & & & & 3000 & & & & & Hladik et al. (2009) \\
\hline & Coldwater R, MS & 921 & 6.3 & & & & & & & & & Knight et al. (2009) \\
\hline & Beasely Lake, MS & 227 & 23.7 & & & & 1.2 & & & & & Lizzotte et al. (2010) \\
\hline & South Florida & 50 & & & & & & & & & & Pfeuffer (2011) \\
\hline & Texas & 37 & & & & & 900 & & & & & Belden et al. (2012) \\
\hline
\end{tabular}


Table 7 Selected recent peer-reviewed studies in Australia (post-2005) and overseas (post-2009) that have used passive samplers for the detection of one or more of the herbicides examined in this study in surface waters (freshwater wetlands, creeks, rivers, lakes and estuaries).

\begin{tabular}{|c|c|c|c|c|c|c|c|c|c|c|c|c|c|c|}
\hline \multirow[t]{2}{*}{ Country } & \multirow[t]{2}{*}{ Region } & \multirow[t]{2}{*}{$\begin{array}{l}\text { Type of } \\
\text { sampler }\end{array}$} & \multirow[t]{2}{*}{$\begin{array}{l}\text { Reporting } \\
\text { mode }\end{array}$} & \multicolumn{10}{|c|}{$\begin{array}{l}\text { Herbicide Concentrations } \\
\quad(\max ; \mathrm{g} / \mathrm{L} \text { or } \mathrm{ng})\end{array}$} & \multirow[t]{2}{*}{ Reference } \\
\hline & & & & ATR & CYN & HEX & LIN & MZN & PEN & PRM & PRO & SIM & TER & \\
\hline & Australia & & & & & & & & & & & & & \\
\hline \multirow[t]{2}{*}{ Victoria } & Yarra Valley & $\mathrm{CC}$ & TWAWC & 0.13 & & 0.05 & & & & & & 3.2 & & This study \\
\hline & Yarra Valley & SPMD & TWAWC & & & & & & 0.002 & & & & 0.005 & This study \\
\hline \multirow[t]{6}{*}{ Queensland } & Wet Tropics region & $\mathrm{CC}$ & TWAWC $*$ & 0.0003 & & 0.00045 & & & & & & 0.0025 & & Shaw et al. (2005) \\
\hline & Noosa National Park & $\mathrm{CC}$ & TWAWC & & & & & & & & & 0.015 & & Escher et al. (2006) \\
\hline & Russell-Mulgrave R & $\mathrm{CC}$ & TWAWC * & 0.035 & & 0.004 & & & & & & & & Shaw et al. (2009) \\
\hline & Moreton Bay & $\mathrm{CC}$ & ng/sampler & 14 & & & & & & & & 41 & & Stephens et al. (2009) \\
\hline & Wet Tropics region & $\mathrm{CC}$ & TWAWC * & 0.045 & & 0.04 & & & & & & & & Shaw et al. (2010) \\
\hline & South-east Qld & $\mathrm{CC}$ & TWAWC & 0.03 & & & & & & & & & & O’Brien et al (2011) \\
\hline \multirow{2}{*}{$\begin{array}{l}\text { New South } \\
\text { Wales }\end{array}$} & $\begin{array}{l}\text { Murrumbidgee } \\
\text { Irrigation Area }\end{array}$ & SPMD & TWAWC $*$ & 0.1 & & & & & & & & & & Hyne and Aistrope (2008) \\
\hline & ternational & & & & & & & & & & & & & \\
\hline \multirow[t]{4}{*}{ France } & $\begin{array}{l}\text { Ruiné and Charente } \\
\text { R, west France }\end{array}$ & POCIS & TWAWC * & 0.02 & & & & & & & & 0.02 & & Mazzella et al (2010) \\
\hline & Ruiné R, west France & POCIS & TWAWC * & 0.012 & & & 0.005 & & & & & 0.042 & & Lissalde et al (2011) \\
\hline & Ruiné R, west France & POCIS & TWAWC * & 0.04 & & & & & & & & 0.085 & & Pesce et al (2011) \\
\hline & Rhone R, Gard & POCIS & TWAWC * & 0.008 & & & & & & & & 0.005 & & Ibrahim et al. (2013) \\
\hline
\end{tabular}


Table 7 (contd)

\begin{tabular}{|c|c|c|c|c|c|c|c|c|c|c|c|c|c|c|}
\hline \multirow[t]{2}{*}{ Country } & \multirow[t]{2}{*}{ Region } & \multirow[t]{2}{*}{$\begin{array}{l}\text { Type of } \\
\text { sampler }\end{array}$} & \multirow[t]{2}{*}{$\begin{array}{l}\text { Reporting } \\
\text { mode }\end{array}$} & \multicolumn{10}{|c|}{$\begin{array}{l}\text { Herbicide Concentrations } \\
\quad(\max ; \mathrm{g} / \mathrm{L} \text { or } \mathrm{ng})\end{array}$} & \multirow[t]{2}{*}{ Reference } \\
\hline & & & & ATR & CYN & HEX & LIN & MZN & PEN & PRM & PRO & SIM & TER & \\
\hline \multirow{4}{*}{$\begin{array}{l}\text { Spain } \\
\text { UK }\end{array}$} & south east & POCIS & TWAWC & 0.0015 & & & & & & & & 0.0009 & 0.0001 & Martínez Bueno et al (2009) \\
\hline & Portsmouth Harbour & $\mathrm{CC}$ & $\mathrm{ng} / \mathrm{sampler}$ & 6.0 & & & & & & & & & & El-Shenawy et al (2010) \\
\hline & River Thames estuary & PTF & TWAWC * & 0.065 & & & & 0.11 & 0.00004 & & & & & St. George et al (2011) \\
\hline & n.e. Scotland & SRS & $\mathrm{ng} / \mathrm{g}$ sampler & 2.7 & 1.5 & & & & 25 & 1.6 & & 2.4 & 6.4 & Emelogu et al. (2013) \\
\hline USA & Nebraska & POCIS & TWAWC * & 0.98 & & & & & & & & & & Bartelt-Hunt et al (2011) \\
\hline
\end{tabular}

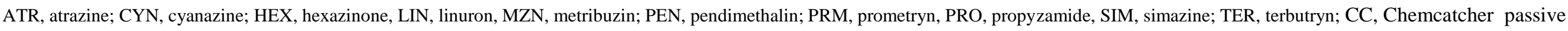

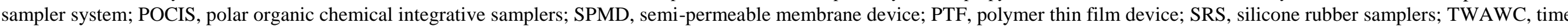

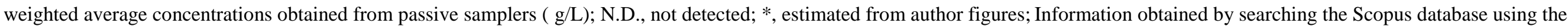

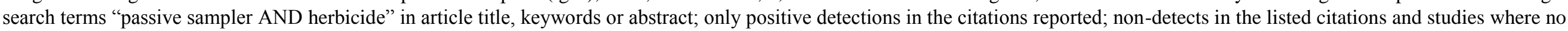
herbicides were examined/detected are not reported. 
Table 8 Summary of ecotoxicological effect data for the herbicides detected

\begin{tabular}{|c|c|c|c|c|c|c|}
\hline \multirow{2}{*}{ Active } & \multirow{2}{*}{ Mode of toxic action } & \multicolumn{4}{|c|}{ Ecotoxicological effect value $^{a}$} & \multirow{2}{*}{$\begin{array}{c}\text { Maximum } \\
\text { concentration in } \\
\text { this study }\end{array}$} \\
\hline & & Fish & $\begin{array}{c}\text { Aquatic } \\
\text { invertebrates }\end{array}$ & $\begin{array}{c}\text { Aquatic } \\
\text { plants }\end{array}$ & Algae & \\
\hline & & \multicolumn{5}{|c|}{$(\mathrm{g} / \mathrm{L})$} \\
\hline atrazine & PS II inhibitor & 2000 & 250 & 19 & 100 & 0.02 \\
\hline hexazinone & PSII inhibitor & - & 50000 & 72 & & 0.005 \\
\hline linuron & PSII inhibitor & 100 & 180 & 17 & 10 & 0.003 \\
\hline pendimethalin & Inhibits mitosis / cell division & 6 & 15 & 12 & & 0.04 \\
\hline simazine & PSII inhibitor & 700 & 2500 & 300 & 600 & 0.67 \\
\hline terbutryn & PSII inhibitor & - & - & - & - & 0.001 \\
\hline
\end{tabular}

${ }^{\text {a }}$ Data from IUPAC Pesticide Properties Database (University of Hertfordshire 2013). Fish and aquatic invertebrates, 21 day NOEC; aquatic plants, 7 day EC 50 (biomass); algae, 96 hour NOEC (growth) 
Figures 


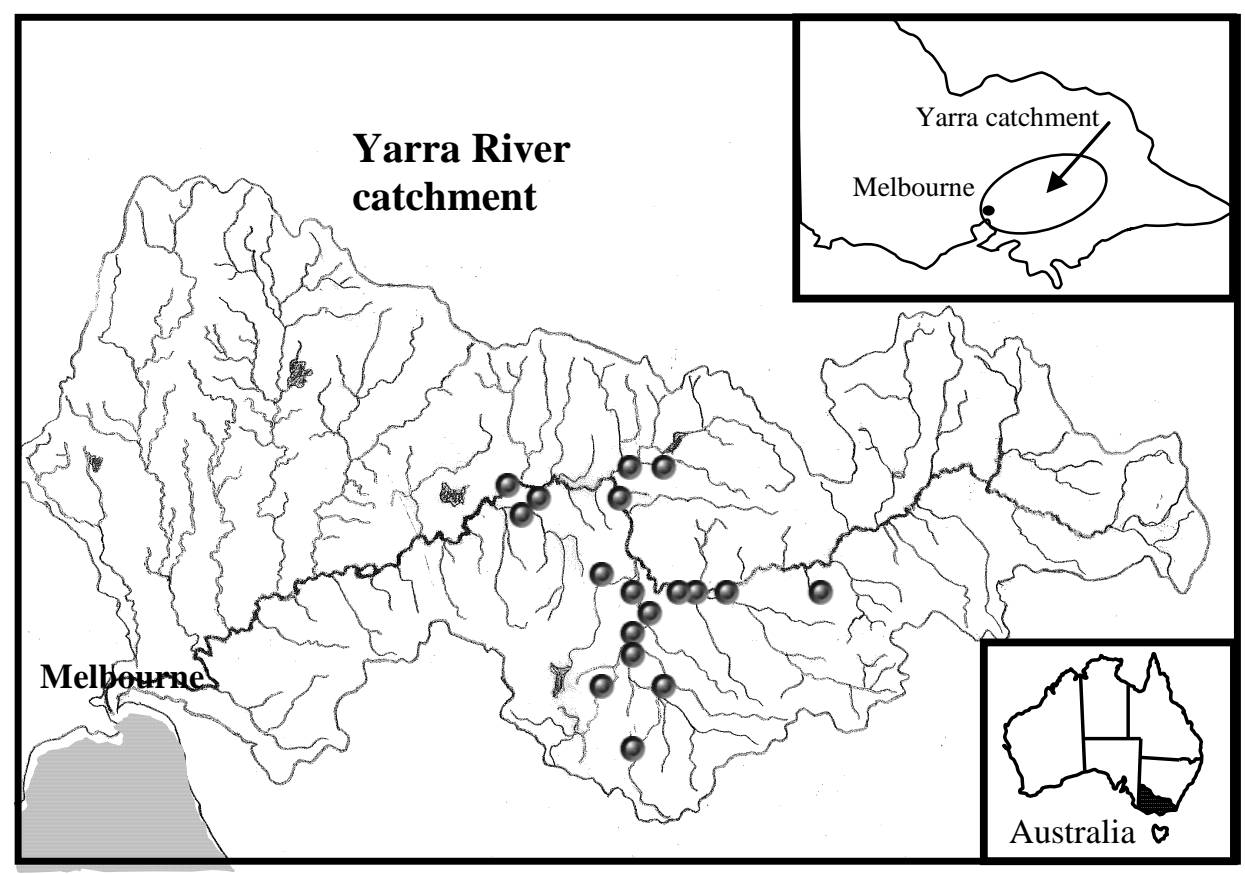

Figure 1 Approximate locations of the 18 monitoring sites (indicated by the circles) in the Yarra River catchment, Victoria, Australia 


\section{University Library}

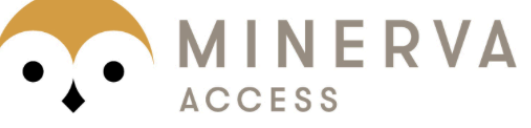

A gateway to Melbourne's research publications

Minerva Access is the Institutional Repository of The University of Melbourne

Author/s:

Allinson, G;AnhDuyen, B;Zhang, P;Rose, G;Wightwick, AM;Allinson, M;Pettigrove, V

Title:

Investigation of 10 Herbicides in Surface Waters of a Horticultural Production Catchment in Southeastern Australia

Date:

2014-10-01

\section{Citation:}

Allinson, G., AnhDuyen, B., Zhang, P., Rose, G., Wightwick, A. M., Allinson, M. \& Pettigrove, V. (2014). Investigation of 10 Herbicides in Surface Waters of a Horticultural Production Catchment in Southeastern Australia. ARCHIVES OF ENVIRONMENTAL CONTAMINATION AND TOXICOLOGY, 67 (3), pp.358-373. https://doi.org/10.1007/s00244-014-0049-z.

Persistent Link:

http://hdl.handle.net/11343/282952 